\title{
Calcium and vitamin $D$ in obesity
}

\author{
Qingming Song and Igor N. Sergeev* \\ Department of Health and Nutritional Sciences, South Dakota State University, Brookings, SD 57007, USA
}

\section{Abstract}

New and more effective nutritional measures are urgently needed for the prevention of obesity. The role of Ca and vitamin D in obesity has been recently implicated. Low Ca intake and low vitamin D status have been linked with an increased risk of obesity in epidemiological studies; however, clinical intervention trials designed to test this association have produced controversial results. The suggested anti-obesity mechanisms of $\mathrm{Ca}$ and vitamin $\mathrm{D}$ include the regulation of adipocyte death (apoptosis), adipogenesis and lipid metabolism. Dietary Ca has been also shown to increase faecal fat excretion. The potential role of $\mathrm{Ca}$ and vitamin $\mathrm{D}$ in shifting energy balance towards a more negative state is an area of considerable interest. Ultimately, a review of recent research findings does not allow the reaching of a definitive conclusion that increasing Ca intake and rising vitamin D status will influence fat mass and body weight or decrease the risk of obesity and overweight.

Key words: Calcium: Vitamin D: Obesity: Apoptosis: 1,25-Dihydroxyvitamin $\mathrm{D}_{3}$ : Intracellular $\mathrm{Ca}^{2+}$ : Adipocytes

\section{Introduction}

Obesity is an emerging health problem of growing importance, and new and more effective nutritional measures are urgently needed for the prevention of this disease. While the aetiology of obesity is multifactorial, the major factors in the modern obesity epidemic are of dietary origin ${ }^{(1,2)}$.

Although the regulation of energy balance is the most critical factor in maintaining body composition, emerging evidence suggests that $\mathrm{Ca}$ and vitamin $\mathrm{D}$ may play a role in the regulation of weight gain, particularly when included in an energy-restricted diet. However, the results of clinical studies are inconclusive and the possible mechanisms linking dietary $\mathrm{Ca}$ intake and vitamin $\mathrm{D}$ status with obesity remain undefined. The aim of the present review is to provide a comprehensive assessment of the role of $\mathrm{Ca}$ and vitamin $\mathrm{D}$ in weight gain, overweight and obesity.

\section{Obesity and adipose tissue}

Obesity is associated with multiple disease outcomes, including heart disease, diabetes, stroke, the metabolic syndrome and a number of cancers ${ }^{(3,4)}$, as well being linked to increased mortality rates ${ }^{(5)}$. BMI, which estimates human body fat based on an individual's weight and height, is commonly used as a surrogate measure of overall obesity ${ }^{(6)}$. Although other factors such as muscularity may affect BMI, the amount of body fat significantly contributes to weight excess or deficiency. Therefore, studies usually report body weight and BMI as outcomes.

Lifestyle and behavioural factors such as energy intake together with levels of physical activity play critical roles in the obesity epidemic. The United States Department of Agriculture reported that total daily energy intake increased from $9071 \mathrm{~kJ}$ ( $2168 \mathrm{kcal})$ in 1970 to $11184 \mathrm{~kJ}$ (2673 kcal) in $2008^{(7)}$. In modern urban-industrial society, a sedentary lifestyle is commonly found in both the developed and developing countries. At least $60 \%$ of the world's population does not engage in the recommended amount of physical activity ${ }^{(2)}$. Inactivity is associated with increasing age, smoking, poverty, less education, and is more common among women than men. In addition, a number of genes are known to have contributions in defining the obese phenotype. Genetic and environmental inheritance may account for $70 \%$ of the population variation in $\mathrm{BMI}^{(8)}$. Current obstacles for the development of the effective prevention and treatment approaches to obesity include lack of understanding of genomic, epigenetic, metabolic and signalling pathways underlying this condition/disease.

Obesity is characterised by the accumulation of adipose tissue mass, which can result from both hypertrophy, an increase in adipocyte size, and hyperplasia, an increase in adipocyte number ${ }^{(9)}$. An obese individual can accumulate more than $70 \%$ of body mass as fat ${ }^{(10)}$. There are two types of

Abbreviations: 25(OH)D, 25-hydroxyvitamin D; 1,25(OH) $2 \mathrm{D}_{3}, 1,25$-dihydroxyvitamin $\mathrm{D}_{3} ; 25(\mathrm{OH}) \mathrm{D}_{3}$, 25-hydroxyvitamin $\mathrm{D}_{3}$; UCP, uncoupling protein; VDR, vitamin D receptor.

*Corresponding author: Dr Igor N. Sergeev, fax +1 11605688 5603, email igor.sergeev@sdstate.edu 
adipose tissue: white adipose tissue and brown adipose tissue. The white adipocytes contain a single large lipid droplet, which squeezes the nucleus into a thin rim at the periphery. They express insulin, growth hormone, adrenergic, glucocorticoid, retinoid and vitamin D receptors (VDR). Brown adipocytes contain numerous smaller lipid droplets and a large number of mitochondria. They are especially abundant in newborns and in hibernating mammals ${ }^{(11)}$. Adipose tissue depots are found in specific locations subcutaneous, intra-abdominal and perirenal - and they may perform different functions ${ }^{(12,13)}$. An excess of visceral fat that is packed in between internal organs has a strong association with several health disorders such as heart disease, cancer and stroke ${ }^{(14)}$.

Adipose tissue performs important functions, with longterm energy storage being an essential function ${ }^{(15)}$. Adaptive increases of adipose tissue play a key role for birds and mammals living in a cold environment. Bergmann's rule indicates the tendency for the body size of birds and mammals to be larger in cooler climates ${ }^{(16)}$. Adipose tissue also stores cholesterol and lipid-soluble vitamins, in particular vitamin $\mathrm{D}^{(17)}$. It is now appreciated that white adipose tissue serves as an important endocrine organ by secreting hormones such as leptin, resistin, cytokines (including $\mathrm{TNF} \alpha$ ), adiponectin and steroids ${ }^{(18)}$. Brown adipose tissue plays a key role in generating heat (instead of ATP) by uncoupling mitochondria ${ }^{(19)}$.

Vitamin D and Ca play a critical, interlinked role not only in performing their classical functions related to mineral metabolism, but also in a number of signalling pathways that regulate a variety of cellular and physiological processes, including those in adipose tissue. Recently, the role of $\mathrm{Ca}$ and vitamin $\mathrm{D}$ in obesity has been implicated, and increasing dietary Ca intake and vitamin D status has been proposed as a promising strategy for the prevention of obesity.

\section{Calcium and obesity \\ Calcium as a cellular regulator}

Ca performs its regulatory functions at the cellular level in the form of $\mathrm{Ca}^{2+}$ ions. $\mathrm{Ca}^{2+}$ is considered as the most versatile, ubiquitous intracellular messenger ${ }^{(20-23)}$. It reversibly binds to specific proteins that act as $\mathrm{Ca}^{2+}$ sensors to decode its information before passing it on to targets. The membrane $\mathrm{Ca}^{2+}$ transport systems control the cellular homeostasis of $\mathrm{Ca}^{2+}$. Remarkably, $\mathrm{Ca}^{2+}$ is a universal, ambivalent signalling agent. It carries information to virtually all processes important to cell life, but also transmits signals that promote cell death. Spatial and temporal characteristics of the $\mathrm{Ca}^{2+}$ signal determine the type and magnitude of biological responses; for example, oscillations of cytosolic $\mathrm{Ca}^{2+}$ in pancreatic $\beta$-cells underlie the oscillatory pattern of insulin release ${ }^{(24,25)}$.

\section{Calcium intake}

The dietary reference intake for $\mathrm{Ca}$ was updated by the United States Food and Nutrition Board of the Institute of Medicine in 2010, with the biggest change made being the conversion from adequate intake to estimated average requirement and $\mathrm{RDA}^{(26,27)}$. The RDA varies from $700 \mathrm{mg} / \mathrm{d}$ for younger children to $1300 \mathrm{mg} / \mathrm{d}$ for adolescents; $1200 \mathrm{mg} / \mathrm{d}$ should be considered sufficient for most groups. The nutritional guidelines provided by the European Union Commission are similar ${ }^{(28)}$.

The best source of Ca is dairy foods ${ }^{(29)}$. Although some individuals are intolerant to dairy products or do not consume dairy products for ethical reasons, other good sources of $\mathrm{Ca}$ exist. However, Ca deficiency is still an important issue. Adolescents and older individuals are the most likely groups to be deficient in $\mathrm{Ca}^{(30)}$, and $\mathrm{Ca}$ deficiency is considered in the USA to warrant a national effort to increase average intake levels ${ }^{(31)}$.

\section{Calcium and body mass}

A growing body of literature suggests that a low Ca intake is associated with a greater fat mass. The potential effect of $\mathrm{Ca}$ on weight loss has been shown in animal models ${ }^{(32-35)}$. Importantly, the results obtained with murine models of obesity appear to translate to humans. Several observational studies (mainly cross-sectional and retrospective cohort studies) $)^{(36-42)}$ have demonstrated a negative relationship between $\mathrm{Ca}$ intake and body weight. Furthermore, this association has been observed across multiple ages and ethnicities and in both sexes. However, it is necessary to consider that the overall energy density of diets characterised by a low $\mathrm{Ca}$ content can be higher than comparable diets characterised by a high $\mathrm{Ca}$ content ${ }^{(41)}$. Moreover, daily food consumption in experimental animals fed a high-Ca diet ad libitum can be lower than that of animals fed diets with normal or low Ca levels. These observations may provide an additional explanation of the possible effect of $\mathrm{Ca}$ on body weight.

The intervention studies examining the effects of $\mathrm{Ca}$ on body weight are summarised in Table 1 . The studies conducted during an energy-restriction programme demonstrated that $\mathrm{Ca}$ intake has no significant effect on body weight ${ }^{(43-48)}$. Importantly, the studies conducted without requiring energy restriction failed to demonstrate the effect of $\mathrm{Ca}$ intake on body-weight loss as well ${ }^{(49,50)}$. Several studies showed no effect of a high $\mathrm{Ca}$ intake on bodyweight loss ${ }^{(44,46,47,49,50)}$, although one of these studies demonstrated a significant increase in fat oxidation ${ }^{(46)}$. The meta-analysis review that included randomised controlled trials also failed to find evidence of a beneficial effect of $\mathrm{Ca}$ on body weight ${ }^{(51)}$. A study conducted by Torres et al. ${ }^{(52)}$ found that subjects consuming a diet containing 1200$1300 \mathrm{mg}$ Ca per d exhibited a greater reduction in waist circumference and waist:hip ratio as compared with subjects 
Table 1. Intervention studies examining the effects of calcium on body weight

\begin{tabular}{|c|c|c|c|c|}
\hline Reference & Population & Design & Intervention & Results \\
\hline Yanovski et al. ${ }^{(49)}$ & $\begin{array}{l}n 340 ; 72 \% \text { female; age } 38.8 \\
(\mathrm{sD} 10 \cdot 5) \text { years; } \mathrm{BMI}>25 \\
\mathrm{~kg} / \mathrm{m}^{2}\end{array}$ & 24 months, no energy restriction & $1500 \mathrm{mg} / \mathrm{d}$ from supplement $(n$ 170); placebo $(n 170)$ & $\begin{array}{l}\text { Dietary supplementation with elemental } \\
\text { Ca had no effect on body weight }\end{array}$ \\
\hline Faghih et al. ${ }^{(45)}$ & $\begin{array}{l}n 85 ; 100 \% \text { female; age } \\
20-50 \text { years; } \mathrm{BMI}>25 \\
\mathrm{~kg} / \mathrm{m}^{2}\end{array}$ & $\begin{array}{l}2 \text { months, energy-restricted diet } \\
(500 \mathrm{kcal} / \mathrm{d} ; 2092 \mathrm{~kJ} / \mathrm{d})\end{array}$ & $\begin{array}{l}800 \mathrm{mg} / \mathrm{d} \text { from supplement }(n 22) ; 800 \mathrm{mg} / \mathrm{d} \text { from milk } \\
(n \text { 22); } 800 \mathrm{mg} / \mathrm{d} \text { from soya milk ( } n 21) ; \text { control diet } \\
(500-600 \mathrm{mg} / \mathrm{d} ; n \text { 20) }\end{array}$ & $\begin{array}{l}\text { Milk decreased body weight and BMI. } \\
\text { Soya milk and Ca supplement had no } \\
\text { effect on body weight or BMI }\end{array}$ \\
\hline Wagner et al. ${ }^{(44)}$ & $\begin{array}{l}n 58 ; 100 \% \text { female; age } \\
19-53 \text { years; BMl } \\
26-41 \mathrm{~kg} / \mathrm{m}^{2}\end{array}$ & $\begin{array}{l}3 \text { months, energy-restricted diet } \\
(500 \mathrm{kcal} / \mathrm{d} ; 2092 \mathrm{~kJ} / \mathrm{d}) ; \text { exercise } \\
\text { three times per week }\end{array}$ & $\begin{array}{l}\text { Control diet }+800 \mathrm{mg} / \mathrm{d} \text { from Ca lactate }(n 12) \text {; control } \\
\text { diet }+800 \mathrm{mg} / \mathrm{d} \text { from calcium phosphate }(n 16) ; \\
\text { control diet }+800 \mathrm{mg} / \mathrm{d} \text { from milk }(n 17) \text {; control diet } \\
(750 \mathrm{mg} / \mathrm{d} ; n 13)\end{array}$ & $\begin{array}{l}\text { Ca did not enhance the loss of body } \\
\text { weight or fat }\end{array}$ \\
\hline Torres et al. ${ }^{(52)}$ & $\begin{array}{l}n 50 ; 90 \% \text { female; age } \\
22-55 \text { years; BMl } \\
30-34.9 \mathrm{~kg} / \mathrm{m}^{2}\end{array}$ & $\begin{array}{l}16 \text { weeks, energy-restricted diet } \\
(800 \mathrm{kcal} / \mathrm{d} ; 3347 \mathrm{~kJ} / \mathrm{d})\end{array}$ & $\begin{array}{l}\text { High-Ca diet }(1200-1300 \mathrm{mg} / \mathrm{d} \text { from milk; } n \text { 25); low- } \\
\text { Ca diet }(<500 \mathrm{mg} / \mathrm{d} ; n \text { 25) }\end{array}$ & $\begin{array}{l}\text { Ca had no effect on body weight, but } \\
\text { showed effect on waist circumference } \\
\text { and waist:hip ratio }\end{array}$ \\
\hline Teegarden et al. ${ }^{(46)}$ & $\begin{array}{l}n 24 ; 100 \% \text { female; age } \\
18-31 \text { years; BMl } \\
25-34.9 \mathrm{~kg} / \mathrm{m}^{2}\end{array}$ & $\begin{array}{l}3 \text { months, energy-restricted diet } \\
(500 \mathrm{kcal} / \mathrm{d} ; 2092 \mathrm{~kJ} / \mathrm{d})\end{array}$ & $\begin{array}{l}900 \mathrm{mg} / \mathrm{d} \text { from supplement }(n 6) ; 900 \mathrm{mg} / \mathrm{d} \text { from dairy } \\
(n 9) ;<500 \mathrm{mg} / \mathrm{d}(n 9)\end{array}$ & $\begin{array}{l}\text { Ca increased fat oxidation, but did not } \\
\text { change total energy expenditure }\end{array}$ \\
\hline Riedt et al. ${ }^{(47)}$ & $\begin{array}{l}n 44 ; 100 \% \text { female; age } 38 \\
\text { (SD 6.4) years; BMI } 27.7 \\
\text { (SD 2.1) } \mathrm{kg} / \mathrm{m}^{2}\end{array}$ & $\begin{array}{l}6 \text { months, weight-loss or weight-main- } \\
\text { tenance diet }\end{array}$ & $\begin{array}{l}\text { Weight-loss diet with } 1800 \mathrm{mg} / \mathrm{d}(n \text { 14); weight- } \\
\text { maintenance diet with } 1000 \mathrm{mg} / \mathrm{d}(n 13) \text {; weight-loss } \\
\text { diet with } 1000 \mathrm{mg} / \mathrm{d}(n 17)\end{array}$ & Ca did not enhance loss of body weight \\
\hline Chailurkit et al. ${ }^{(50)}$ & $\begin{array}{l}\text { 236; } 100 \% \text { female; age } \\
60-97 \text { years; BMI } 25.0 \\
\text { (SD } 3.5) \mathrm{kg} / \mathrm{m}^{2}\end{array}$ & 24 months, no energy restriction & $500 \mathrm{mg} / \mathrm{d}$ from supplement $(n 175) ;$ placebo $(n 161)$ & Ca had no effect on body weight \\
\hline Thomas et al. ${ }^{(48)}$ & $\begin{array}{l}n 29 ; 100 \% \text { female; age } \\
36.8(\text { SD } 4.8) \text { years; BMI } \\
29.1(\text { SD } 2 \cdot 1) \mathrm{kg} / \mathrm{m}^{2}\end{array}$ & $\begin{array}{l}16 \text { weeks, energy-restricted diet } \\
(250 \mathrm{kcal} / \mathrm{d} ; 1046 \mathrm{~kJ} / \mathrm{d}) \text { and resist- } \\
\text { ance training } 3 \mathrm{~d} / \mathrm{week}\end{array}$ & $\begin{array}{l}\leq 500 \mathrm{mg} \text { low-Ca diet/d }(n 15) ; \geq 1200 \mathrm{mg} \mathrm{Ca} / \mathrm{d} \text { from } \\
\text { dairy }(n 14)\end{array}$ & $\begin{array}{l}\text { Dairy } \mathrm{Ca} \text { had no added benefit on } \\
\text { body-fat loss }\end{array}$ \\
\hline
\end{tabular}


who consumed a similar diet with a low $\mathrm{Ca}$ content $(<500 \mathrm{mg} / \mathrm{d})$. However, there were no statistically significant differences between groups with respect to body weight. Faghih et $a l^{(45)}$ found an inverse relationship between dairy Ca consumption and body weight, but there were no significant differences between body weight and BMI in the soya milk, Ca supplement and control groups.

Generally, results of the reviewed studies failed to demonstrate the direct effect of dietary Ca on body weight; however, several studies suggest the role of $\mathrm{Ca}$ in increasing fat oxidation and decreasing waist circumference. The inconsistency between observational studies and randomised controlled trials might arise from missing data on energy intake and physical activity in most observational studies (we found only one study demonstrating that, in adolescents, a lower Ca intake is accompanied by a higher intake of fat and energy ${ }^{(41)}$ ).

\section{Vitamin D and obesity}

\section{Vitamin D as a hormonal and cellular regulator}

The biological effects of vitamin $\mathrm{D}_{3}$ result from its sequential metabolism in the liver into 25-hydroxyvitamin $\mathrm{D}_{3}$ $\left(25(\mathrm{OH}) \mathrm{D}_{3}\right)$, and then in the kidney into the steroid hormone 1,25-dihydroxyvitamin $\mathrm{D}_{3} \quad\left(1,25(\mathrm{OH})_{2} \mathrm{D}_{3}\right)^{(53)}$. $1,25(\mathrm{OH})_{2} \mathrm{D}_{3}$ is considered as the principal $\mathrm{Ca}^{2+}$-regulatory hormone, which exerts its regulatory effects by increasing intestinal $\mathrm{Ca}^{2+}$ absorption, bone $\mathrm{Ca}^{2+}$ mobilisation and renal $\mathrm{Ca}^{2+}$ reabsorption ${ }^{(21,53,54)} \cdot 1,25(\mathrm{OH})_{2} \mathrm{D}_{3}$ regulates not only $\mathrm{Ca}^{2+}$ metabolism, but also a wide spectrum of cellular processes, including proliferation, differentiation, development, apoptosis and secretion ${ }^{(21,25,55,56)} \cdot 1,25(\mathrm{OH})_{2} \mathrm{D}_{3}$ produces its biological effects via both receptor-mediated regulation of nuclear events and rapid actions independent of genomic pathways ${ }^{(21,55,57)}$. The genomic responses utilise signal-transduction pathways linked to the nuclear/cytosolic VDR, while the rapid responses utilise signal-transduction pathways linked to the membrane VDR localised in the plasma and, possibly, endoplasmic reticulum membranes $^{(58)}$ as well as to the plasma membrane-associated rapid response steroid hormone-binding protein ${ }^{(59,60)}$.

Nuclear and membrane VDR have been demonstrated in many (over forty) tissues, including adipose tissue ${ }^{(21,53,61)}$. In these target tissues, the VDR functions both as a transcriptional factor to influence more than $3 \%$ of the human genome and a modulator of a number of cellular signal-transduction pathways, including $\mathrm{Ca}^{2+}$ signalling. Analogues of vitamin D that can act as agonists of genomic and non-genomic pathways have been identified ${ }^{(62-64)}$. It appears that $\mathrm{Ca}^{2+}$ signals (transient and prolonged) triggered by $1,25(\mathrm{OH})_{2} \mathrm{D}_{3}$ can be linked to both membrane and nuclear $\mathrm{VDR}^{(22,65)}$.

Significant evidence indicates that biological actions of $1,25(\mathrm{OH})_{2} \mathrm{D}_{3}$ are mediated or influenced by intracellular $\mathrm{Ca}^{2+}$-signalling events. Rapid (within seconds to minutes) effects of $1,25(\mathrm{OH})_{2} \mathrm{D}_{3}$ on intracellular $\mathrm{Ca}^{2+}$ have been demonstrated in mammary and intestinal epithelial cells, pancreatic $\beta$-cells, osteoblasts and adipocytes ${ }^{(21,25,55,56,66-69)}$. It has been also shown that $1,25(\mathrm{OH})_{2} \mathrm{D}_{3}$ rapidly induces $\mathrm{Ca}^{2+}$ uptake, activates $\mathrm{Ca}^{2+}$ channels and stimulates phosphoinositide turnover in different cell types ${ }^{(55,57,63)}$. Thus, activation of the intracellular $\mathrm{Ca}^{2+}$-signalling pathways is essential for the actions of $1,25(\mathrm{OH})_{2} \mathrm{D}_{3}$. It is interesting to note that, in turn, $\mathrm{Ca}^{2+}$ can interact with the VDR via $\mathrm{Ca}^{2+}$-binding $\gamma$-carboxyglutamate residues of the receptor protein, which results in down-regulation of the vitamin D-mediated biological responses ${ }^{(61,70,71)}$.

\section{Determination of vitamin D status}

Vitamin D status is determined by measuring the circulating concentration of its transport form, 25-hydroxyvitamin $\mathrm{D}(25(\mathrm{OH}) \mathrm{D})$. The serum concentration of $25(\mathrm{OH}) \mathrm{D}$ is approximately 1000 times higher than that of $1,25(\mathrm{OH})_{2} \mathrm{D}$, and $25(\mathrm{OH}) \mathrm{D}$ has a half-life of $2-3$ weeks compared with that of $4-6 \mathrm{~h}$ for the hormone ${ }^{(72)}$. The circulating concentration of $25(\mathrm{OH}) \mathrm{D}$ is considered to be the most reliable indicator of vitamin D production, intake and stores $^{(73)}$.

Currently, there is no consensus on how the circulating levels of $25(\mathrm{OH}) \mathrm{D}$ should be classified to describe vitamin $\mathrm{D}$ nutritional status. The concentration of $25(\mathrm{OH}) \mathrm{D}$ in severe vitamin D deficiency is 'undetectable' (i.e. $<1-5 \mathrm{ng} / \mathrm{ml}$ ); normal range is traditionally defined as $20-50 \mathrm{ng} / \mathrm{ml}$; levels below $10-20 \mathrm{ng} / \mathrm{ml}$ may indicate vitamin D insufficiency, while levels above $100 \mathrm{ng} / \mathrm{ml}$ represent a risk of toxicity ${ }^{(26,27)}$. A higher range of normal or 'optimal' 25(OH)D concentrations have been also suggested (for example, $30-70 \mathrm{ng} / \mathrm{ml})^{(74)}$.

Vitamin D status depends on sunlight exposure and dietary intake. The skin has a large vitamin $D_{3}$ production capacity and is capable of supplying body requirements in vitamin D. Latitude, season, skin pigmentation, sunscreen use and ozone air pollution influence the cutaneous production of vitamin $\mathrm{D}_{3}$. The levels of UVB irradiation to produce a significant increase in the serum $25(\mathrm{OH}) \mathrm{D}$ concentration are not possible to achieve in winter at latitudes above and below $40^{\circ}$, thus limiting endogenous production of vitamin $\mathrm{D}_{3}$ for several months of the year ${ }^{(75)}$ Consumption of dietary or supplemental vitamin $\mathrm{D}$ or artificial UV irradiation should be considered under these circumstances $^{(26)}$.

The dietary reference intake allowance of vitamin D the value sufficient to meet the needs of virtually all individuals - recommended in 2010 by the United States Food and Nutrition Board of the Institute of Medicine is $15 \mu \mathrm{g} / \mathrm{d}(600 \mathrm{IU} / \mathrm{d})^{(26)}$. For infants, adequate intake is $10 \mu \mathrm{g} / \mathrm{d}(400 \mathrm{IU} / \mathrm{d})$. Estimated average requirement of vita$\min \mathrm{D}$ is $400 \mathrm{IU} / \mathrm{d}$ for all life-stage groups (it is not established for infants). Possible benefits of vitamin D intake at the level of $2000-4000 \mathrm{IU} / \mathrm{d}(25-100 \mu \mathrm{g} / \mathrm{d})$ are actively 
debated $^{(74)}$. The Institute of Medicine does not recommend such an increase ${ }^{(26)}$. The recommended upper intake level of vitamin D for adults is $4000 \mathrm{IU} / \mathrm{d}(100 \mu \mathrm{g} / \mathrm{d})^{(26)}$; longterm intake at the level of 5000-10 $000 \mathrm{IU} / \mathrm{d}$ may represent a risk of toxicity. The nutritional guidelines for vitamin D set forward by the European Union Commission are similar $^{(28)}$. The US and European Union recommendations are based on the established actions of vitamin $\mathrm{D}$ on $\mathrm{Ca}$ and bone metabolism.

\section{Vitamin D status and obesity}

The potential link between vitamin D and obesity was first observed in 1971 by Rosenstreich et al. ${ }^{(76)}$. They demonstrated the association between increased body fat and low serum $25(\mathrm{OH}) \mathrm{D}$ concentrations and attributed this to sequestration of the fat-soluble vitamin $\mathrm{D}$ in the adipose tissue. Zemel et al. ${ }^{(77)}$ showed that dietary Ca can reduce adiposity and suggested that the regulation by $\mathrm{Ca}$ of the production of $1,25(\mathrm{OH})_{2} \mathrm{D}$ plays a role. These two studies laid the groundwork for examining the connection between vitamin $\mathrm{D}$ and body composition as well as for elucidating the underlying mechanisms.

Recently, a growing body of epidemiological evidence has emerged suggesting the role of vitamin D in obesity, including observational studies that demonstrated the association between vitamin D intake and body composition $^{(42,75,78-100)}$. In these studies, a statistically significant inverse correlation suggesting that a low vitamin D status is associated with a larger fat mass as well as a greater risk of weight gain over time has been reported. However, it is important to mention that obese individuals have limited mobility and avoid outdoor activity ${ }^{(101)}$. In those individuals, exposure of skin to UVB irradiation may become inadequate to maintain optimal vitamin D status ${ }^{(102)}$. It is also important to mention that vitamin $\mathrm{D}_{3}$ is sequestrated in the obese adipose tissue ${ }^{(103)}$. These should be taken into consideration in explaining the inverse correlation between vitamin D status and body weight demonstrated in observational studies.

The effect of vitamin D supplementation (often together with an increased dietary Ca intake) on body fat in human subjects has been evaluated in several randomised controlled trials (Table 2) ${ }^{(104-109)}$. The 4 -year study by Caan et al. ${ }^{(109)}$ demonstrated that the consumption of $1000 \mathrm{mg}$ Ca plus 400 IU vitamin D per d has a small effect on the prevention of weight gain, which was observed primarily in women who reported inadequate $\mathrm{Ca}$ intakes. In contrast, in five studies no effect was demonstrated ${ }^{(104-108)}$. For example, the 15-week weight-loss study by Major et al. ${ }^{(106)}$ showed that the consumption of $600 \mathrm{mg}$ Ca plus $1100 \mathrm{IU}$ vitamin D per d enhanced the beneficial changes in HDLcholesterol, TAG and total cholesterol in overweight or obese women with a low daily Ca intake, but had no effect on body weight. The study by Zhou et al. ${ }^{(108)}$ demonstrated that percentage of trunk fat was significantly different between the $\mathrm{Ca}$ intervention groups and the placebo group, but vitamin D supplementation had no additional effect. Furthermore, the 1-year study conducted by Zittermann et al. ${ }^{(104)}$ in Norway revealed that a significant weight reduction in overweight and obese subjects is unlikely to occur with vitamin D supplementation.

The results of observational studies and randomised controlled trials do not provide conclusive causal or mechanistic insights into whether or how vitamin D (and Ca) might regulate body weight. It is necessary to note that confounding effects could explain the association between vitamin D levels and fat stores in a non-casual or reversecasual way; for example, low 25(OH)D levels in obesity could be observed because of its increased sequestration in the obese adipose tissue or because higher levels of physical outdoor activities could increase sun exposure and $25(\mathrm{OH}) \mathrm{D}$ levels or decrease adiposity directly.

\section{Mechanisms of action of calcium and vitamin D in obesity}

The research employing cellular and animal models identified several mechanisms of action of $\mathrm{Ca}$ and vitamin $\mathrm{D}$ in adipose tissue supporting their possible involvement in the regulation of body weight.

\section{Calcium intake and faecal fat excretion}

Ca can impair the absorption of fat in the intestine via formation of insoluble Ca fatty acid soaps or by binding of bile acids. This mechanism was demonstrated in animal and human studies, indicating that supplemental $\mathrm{Ca}$ and dairy foods increase faecal excretion of fat. deWit et al. ${ }^{(35)}$ observed a significant increase in the faecal excretion of fatty acids and bile acids in mice fed a high-Ca diet. Buchowski et al. ${ }^{(110)}$ also found that a high-Ca diet causes an increase in faecal fat excretion independent of the Ca source. Specifically, they showed that, compared with a low-Ca diet, a high-Ca diet increased the faecal fat excretion in human subjects by $1.8 \mathrm{~g} / \mathrm{d}$, or about $3 \%$ of daily fat intake. This increase in fat excretion could cause $0.4-0.7 \mathrm{~kg}$ of body-fat loss over a 1 -year period. Christensen et al. ${ }^{(111)}$ examined the effect of $\mathrm{Ca}$ on fat excretion by performing a systematic meta-analysis review and estimated that increasing daily $\mathrm{Ca}$ intake by $1241 \mathrm{mg} / \mathrm{d}$ resulted in an increase in faecal fat of $5 \cdot 2(1.6-8.8) \mathrm{g} / \mathrm{d}$. This effect was most pronounced in subjects with a low habitual dietary $\mathrm{Ca}$ intake. However, the effect of $\mathrm{Ca}$ on faecal fat excretion has not been investigated in longterm studies.

\section{Intracellular calcium, 1,25-dihydroxyvitamin $D_{3}$ and apoptosis}

Apoptosis, a highly regulated form of cell death, plays an important role during development and adult life via intimate involvement in cellular and tissue homeostasis. 
Table 2. Intervention studies examining the effects of vitamin $D$ on body weight*

\begin{tabular}{|c|c|c|c|c|}
\hline Reference & Population & Design & Intervention & Results \\
\hline Sneve et al. ${ }^{(105)}$ & $\begin{array}{l}n 445 ; 83 \% \text { female; age } 47.6(\mathrm{SD} 11.4) \\
\text { years; BMl } 28.0-47.0 \mathrm{~kg} / \mathrm{m}^{2} ; \text { serum } \\
\text { 25(OH)D at baseline } 53.1(\mathrm{SD} 16.9) \\
\text { nmol/l }\end{array}$ & $\begin{array}{l}\text { Length } 12 \text { months; latitude } \\
70^{\circ} \mathrm{N}\end{array}$ & $\begin{array}{l}\text { Ca } 500 \mathrm{mg} / \mathrm{d}+40000 \mathrm{IU} \text { vitamin } \mathrm{D}_{3} \text { per } \\
\text { week }(n 153) ; \mathrm{Ca} 500 \mathrm{mg} / \mathrm{d}+20000 \mathrm{IU} \\
\text { vitamin } \mathrm{D}_{3} \text { per week }(n 143) ; \mathrm{Ca} \\
500 \mathrm{mg} / \mathrm{d}+\text { placebo twice per week } \\
(n 149)\end{array}$ & $\begin{array}{l}\text { No significant difference in changes in body } \\
\text { weight, body fat and BMI was observed } \\
\text { between groups }\end{array}$ \\
\hline Zhou et al. ${ }^{(108)}$ & $\begin{array}{l}n \text { 1179; } 100 \% \text { female; age } 66.0 \text { (SD } 6.9) \\
\text { years; BMI } 28.8(\text { SD } 5 \cdot 3) \mathrm{kg} / \mathrm{m}^{2} ; \text { serum } \\
25(\mathrm{OH}) \mathrm{D} \text { at baseline } 73.2(\mathrm{SD} 19 \cdot 9) \\
\text { nmol/l }\end{array}$ & Length 4 years; latitude $41^{\circ} \mathrm{N}$ & $\begin{array}{l}\mathrm{Ca}(1400 \text { or } 1500 \mathrm{mg} / \mathrm{d})+\text { placebo }(n 445) \\
\mathrm{Ca}(1400 \text { or } 1500 \mathrm{mg} / \mathrm{d})+\text { vitamin } \mathrm{D}_{3} \\
(1100 \mathrm{IU} / \mathrm{d})(n 446) ; \text { placebo daily }(n 288)\end{array}$ & $\begin{array}{l}\text { Ca had no effect on BMI but significantly } \\
\text { lowered trunk fat, compared with the pla- } \\
\text { cebo group. Vitamin D may have no } \\
\text { additional effect on body composition }\end{array}$ \\
\hline Major et al. ${ }^{(106)}$ & $\begin{array}{l}n 63 ; 100 \% \text { female; age } 43.6 \text { (SD } 5.0) \\
\text { years; BMI } 27.0-40.0 \mathrm{~kg} / \mathrm{m}^{2} ; \text { serum } \\
25(\mathrm{OH}) \mathrm{D} \text { at baseline } \mathrm{N} / \mathrm{A}\end{array}$ & $\begin{array}{l}\text { Length } 15 \text { weeks, } 700 \mathrm{kcal} / \mathrm{d} \\
(2929 \mathrm{~kJ} / \mathrm{d}) \text { energy restric- } \\
\text { tion; latitude } 46^{\circ} \mathrm{N}\end{array}$ & $\begin{array}{l}\mathrm{Ca}(600 \mathrm{mg} / \mathrm{d})+\text { vitamin } \mathrm{D}(200 \mathrm{IU} / \mathrm{d}) \\
\quad(n 30) ; \text { placebo daily }(n 33)\end{array}$ & $\begin{array}{l}\text { Vitamin D plus Ca has no significant effect } \\
\text { on body weight, body fat and BMI }\end{array}$ \\
\hline Caan et al. ${ }^{(109)}$ & $\begin{array}{l}n 36282 ; 100 \% \text { female; age } 50-79 \text { years; } \\
\mathrm{BMI}<25 \text { to }>35 \mathrm{~kg} / \mathrm{m}^{2} ; \text { serum } \\
25(\mathrm{OH}) \mathrm{D} \text { at baseline } \mathrm{N} / \mathrm{A}\end{array}$ & Length 7 years; latitude N/A & $\begin{array}{l}\mathrm{Ca}(1000 \mathrm{mg} / \mathrm{d})+\text { vitamin } \mathrm{D}_{3}(400 \mathrm{IU} / \mathrm{d}) \\
\quad(n 18176) ; \text { placebo daily }(n 18106)\end{array}$ & $\begin{array}{l}\text { Vitamin } \mathrm{D} \text { plus } \mathrm{Ca} \text { has a small effect on } \\
\text { body weight with inadequate } \mathrm{Ca} \text { intakes }\end{array}$ \\
\hline Zittermann et al. ${ }^{(104)}$ & $\begin{array}{l}n 165 ; 69 \% \text { female; age } 18-70 \text { years; BMI } \\
\quad<25 \text { to }>35 \mathrm{~kg} / \mathrm{m}^{2} ; \text { mean serum } \\
\text { 25(OH)D baseline } 30 \mathrm{nmol} / \mathrm{l}\end{array}$ & $\begin{array}{l}\text { Length } 12 \text { months, weight- } \\
\text { reduction programme; } \\
\text { latitude } 48^{\circ} \mathrm{N}\end{array}$ & $\begin{array}{l}\text { Vitamin } \mathrm{D}_{3}(3332 \mathrm{IU} / \mathrm{d}) \text { ( } n \text { 82); placebo daily } \\
(n \text { 83) }\end{array}$ & $\begin{array}{l}\text { No significant difference in changes of body } \\
\text { weight, body fat and BMI was observed } \\
\text { between groups }\end{array}$ \\
\hline Holecki et al. ${ }^{(107)}$ & $\begin{array}{l}n 40 ; 100 \% \text { female; age } 45-55 \text { years; } \\
\mathrm{BMI}>30 \mathrm{~kg} / \mathrm{m}^{2} ; \text { serum } 25(\mathrm{OH}) \mathrm{D} \text { at } \\
\text { baseline N/A }\end{array}$ & $\begin{array}{l}\text { Length } 3 \text { months, } 1000- \\
1200 \mathrm{kcal} / \mathrm{d}(4184- \\
5021 \mathrm{~kJ} / \mathrm{d}) \text { energy restric- } \\
\text { tion; latitude } 52^{\circ} \mathrm{N}\end{array}$ & $\begin{array}{l}\text { Control diet with Ca }(2000 \mathrm{mg} / \mathrm{d})+\text { vitamin } \\
\mathrm{D}_{3}(250 \mathrm{IU} / \mathrm{d})(n 20) ; \text { control diet }(500 \mathrm{mg} \\
\mathrm{Ca} / \mathrm{d} ; n \text { 20) }\end{array}$ & $\begin{array}{l}\text { No significant difference in changes in body } \\
\text { weight, body fat and BMI was observed } \\
\text { between groups }\end{array}$ \\
\hline
\end{tabular}


Apoptosis is the main mechanism for controlling cell number in most tissues ${ }^{(112)}$. Obesity is the result of an increase in the adipose tissue mass, which can result from both hypertrophy, an increase in adipocyte size, and hyperplasia, an increase in adipocyte number ${ }^{(9,113)}$. Weight loss can be caused not only by a decrease in adipocyte size (i.e. increasing lipolysis with a potential for lipotoxic effects), but also in adipocyte number (for example, by stimulating apoptosis). An increase in the rate of adipocyte apoptosis will prevent excessive accumulation of adipose tissue and may result in a significant loss of adipose tissue mass over time, in contrast to that which occurs after energy restriction. However, studies on the role of apoptosis in fat tissue have been limited by the fact that mature, differentiated adipocytes are extremely stable and not thought to be capable of undergoing apoptosis. Induction of death of adipocytes through apoptosis may emerge as a promising strategy for the prevention and treatment of obesity because removal of adipocytes via this mechanism will result in reducing body fat and a long-lasting maintenance of weight loss.

Cellular $\mathrm{Ca}^{2+}$ has been implicated in the induction of apoptosis and regulation of the apoptotic signalling pathways $^{(20-22,65,114,115)}$; however, mechanisms of $\mathrm{Ca}^{2+}$ signalling in apoptosis remain obscure. We $\mathrm{We}^{(22,55,56,65,68,116-118)}$ and others ${ }^{(20,114,115,119)}$ have shown that increases in the concentration of intracellular $\mathrm{Ca}^{2+}$ occur in the early and late stages of apoptosis. It appears that the critical characteristic of the apoptotic $\mathrm{Ca}^{2+}$ signal is a sustained increase in intracellular $\mathrm{Ca}^{2+}$ concentration, reaching elevated, but not cytotoxic levels. Although there is little doubt that such an increase in intracellular $\mathrm{Ca}^{2+}$ concentration triggers cell death via apoptosis, the mechanisms of action of intracellular $\mathrm{Ca}^{2+}$ in apoptotic pathways are not known and, particularly, interactions of the cellular $\mathrm{Ca}^{2+}$ signal with molecular $\mathrm{Ca}^{2+}$ targets in cells undergoing apoptosis have not been identified. A family of intracellular cysteine proteases, the caspases, is responsible for most biochemical and morphological alterations during apoptosis, although additional or alternative apoptosis initiation and execution pathways have been demonstrated ${ }^{(20,22,120)}$. $\mathrm{Ca}^{2+}$-dependent caspases and $\mathrm{Ca}^{2+}$-dependent neutral proteases, the calpains, are considered as the primary $\mathrm{Ca}^{2+}$-activated apoptotic targets ${ }^{(117,121-125)}$.

Interaction of the $\mathrm{Ca}^{2+}$ signal with intracellular $\mathrm{Ca}^{2+}$ buffers plays a particularly important role in the apoptotic process. A key element of the cytosolic $\mathrm{Ca}^{2+}$-buffering system is the vitamin D-dependent $\mathrm{Ca}^{2+}$-binding proteins, calbindins. Elevated levels of calbindins dramatically increase the cytosolic $\mathrm{Ca}^{2+}$-buffering capacity and an increase in $\mathrm{Ca}^{2+}$ buffering via forced expression of calbindin- $\mathrm{D}_{28 \mathrm{k}}$ protects cells against $\mathrm{Ca}^{2+}$-mediated apoptosis ${ }^{(65,67,69,117)}$.

We have shown ${ }^{(21,22,65)}$ that a sustained (not reaching cytotoxic levels) increase in intracellular $\mathrm{Ca}^{2+}$ concentration signals the cell to enter the apoptotic pathway via activation of the $\mathrm{Ca}^{2+}$-dependent protease $\mu$-calpain followed by activation of the $\mathrm{Ca}^{2+} /$ calpain-dependent caspase-12 and other executor caspases (for example, caspase-3). A lack of expression or low levels of the cytosolic $\mathrm{Ca}^{2+}$-binding proteins (for example, calbindin-D) diminish the ability of the cell to buffer intracellular $\mathrm{Ca}^{2+}$ concentration increases and, thus, facilitate induction of apoptosis. On the other hand, agents that induce expression of the intracellular $\mathrm{Ca}^{2+}$ buffers or suppress pathways for the generation of the apoptotic $\mathrm{Ca}^{2+}$ signal may protect against $\mathrm{Ca}^{2+}$-mediated apoptosis.

It is well established that $1,25(\mathrm{OH})_{2} \mathrm{D}_{3}$ can induce $\mathrm{Ca}^{2+}$ signals in different cell types, including adipocytes. $1,25(\mathrm{OH})_{2} \mathrm{D}_{3}$ activates the voltage-dependent and voltage-insensitive $\mathrm{Ca}^{2+}$ entry pathways and triggers $\mathrm{Ca}^{2+}$ release from the endoplasmic reticulum stores through the inositol 1,4,5-trisphosphate and ryanodine receptors $^{(21,22,56,65,117)}$. Importantly, we have also shown that $1,25(\mathrm{OH})_{2} \mathrm{D}_{3}$ induces apoptosis in adipocytes ${ }^{(23,58)}$ and that apoptosis induced by $1,25(\mathrm{OH})_{2} \mathrm{D}_{3}$ in these cells depends on $\mathrm{Ca}^{2+}$ signalling ${ }^{(22,24,117)}$.

Below we summarise the present results regarding the role of $1,25(\mathrm{OH})_{2} \mathrm{D}_{3}$ in generating $\mathrm{Ca}^{2+}$ signals in adipocytes and provide evidence that $1,25(\mathrm{OH})_{2} \mathrm{D}_{3}$-induced $\mathrm{Ca}^{2+}$ signals can determine adipocyte fate by apoptosis (Fig. 1). These findings may help in the rational search for therapeutic and preventive agents for obesity that act via $\mathrm{Ca}^{2+}$ dependent molecular targets in apoptotic pathways.

\section{1,25-Dihydroxyvitamin $D_{3}$ induces $\mathrm{Ca}^{2+}$-mediated apoptosis in adipocytes}

The mechanism controlling adipocyte apoptosis is unknown and even the ability of adipocytes to undergo apoptosis has not been conclusively demonstrated. We have recently shown ${ }^{(23)}$ that $1,25(\mathrm{OH})_{2} \mathrm{D}_{3}$ induces apoptosis in mature mouse 3T3-L1 adipocytes via activation of the $\mathrm{Ca}^{2+}$-dependent calpain and $\mathrm{Ca}^{2+} /$ calpain-dependent caspase-12. Treatment of adipocytes with $1,25(\mathrm{OH})_{2} \mathrm{D}_{3}$ induced, in a concentration- and time-dependent fashion, a sustained increase in the basal level of intracellular $\mathrm{Ca}^{2+}$. The increase in intracellular $\mathrm{Ca}^{2+}$ concentration was associated with induction of apoptosis and activation of $\mu$-calpain and caspase-12. Importantly, susceptibility of mature, differentiated adipocytes to the $\mathrm{Ca}^{2+}$-elevating effect of $1,25(\mathrm{OH})_{2} \mathrm{D}_{3}$ appears to be dependent on the reduced $\mathrm{Ca}^{2+}$-buffering capacity of these cells. The results demonstrated that $\mathrm{Ca}^{2+}$-mediated apoptosis can be induced in mature, differentiated adipocytes and that the apoptotic molecular targets activated by $1,25(\mathrm{OH})_{2} \mathrm{D}_{3}$ in these cells are $\mathrm{Ca}^{2+}$-dependent calpains and caspases. It is interesting to note that a different class of compounds, flavonoids, which are present in the common human diet, also induces $\mathrm{Ca}^{2+}$-mediated apoptosis in adipocytes ${ }^{(126-128)}$. These findings provide a strong rationale for evaluating the role of vitamin $\mathrm{D}$ in the prevention and treatment of obesity.

$1,25(\mathrm{OH})_{2} \mathrm{D}_{3}$ is not only an important determinant of adipocyte apoptosis, but also appears to regulate adipocyte 


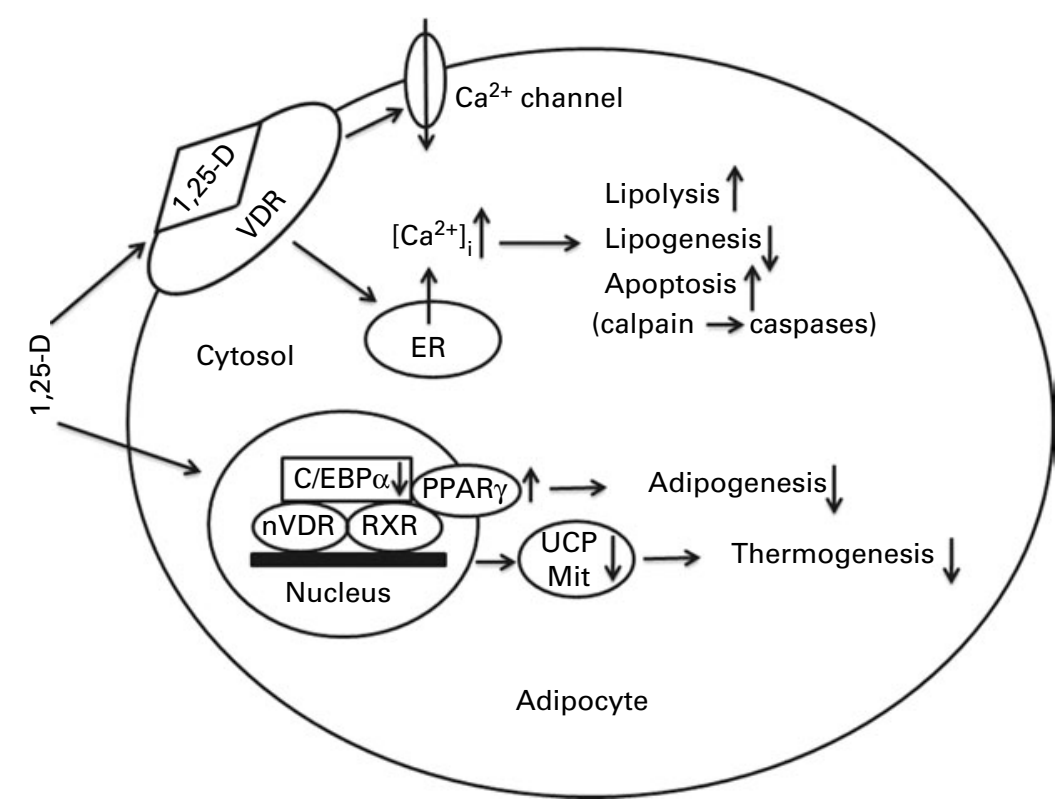

Fig. 1. Role of cellular $\mathrm{Ca}^{2+}$ and 1,25-dihydroxyvitamin $\mathrm{D}_{3}\left(1,25(\mathrm{OH})_{2} \mathrm{D}_{3} ; 1,25-\mathrm{D}\right)$ in the regulation of adipocyte functions. $1,25(\mathrm{OH})_{2} \mathrm{D}_{3}$ generates the cellular $\mathrm{Ca}^{2+}$ signal via the regulation of $\mathrm{Ca}^{2+}$ entry from the extracellular space, $\mathrm{Ca}^{2+}$ mobilisation from the intracellular stores and intracellular $\mathrm{Ca}^{2+}$ buffering. The mechanism includes interactions of $1,25(\mathrm{OH})_{2} \mathrm{D}_{3}$ with the membrane vitamin $\mathrm{D}$ receptor (VDR) and $\mathrm{Ca}^{2+}$ channels/receptors in the plasma and endoplasmic reticulum (ER) membrane. The $1,25(\mathrm{OH})_{2} \mathrm{D}_{3}$-induced cellular $\mathrm{Ca}^{2+}$ signal (a sustained increase in concentration of cytosolic $\mathrm{Ca}^{2+}$ ) inhibits lipogenesis, stimulates lipolysis and induces apoptosis (via activation of the $\mathrm{Ca}^{2+}$-dependent apoptotic pathway) in mature adipocytes. $1,25(\mathrm{OH})_{2} \mathrm{D}_{3}$ also inhibits adipogenesis by suppressing adipocyte differentiation. The process involves down-regulation of a transcriptional factor CCAAT enhancer-binding protein- $\alpha$ (C/EBP $\alpha)$ and upregulation of the nuclear PPAR $\gamma .1,25(\mathrm{OH})_{2} \mathrm{D}_{3}$ appears to inhibit expression of the mitochondrial uncoupling proteins (UCP) in adipocytes, which may counteract body-fat loss (a high UCP expression may promote the shift toward thermogenesis and, thus, a loss of body fat). $\left[\mathrm{Ca}^{2+}\right]_{\mathrm{i}}$, intracellular $\mathrm{Ca}^{2+}$ concentration; nVDR, nuclear VDR; RXR, retinoid X receptor; Mit, mitochondria.

differentiation. It has been shown that $1,25(\mathrm{OH})_{2} \mathrm{D}_{3}$ inhibits adipogenesis in 3T3-L1 cells by blocking their differentiation to mature adipocytes ${ }^{(129)}$. The process involves suppression of a transcriptional regulator CCAAT-enhancer-binding protein $(\mathrm{C} / \mathrm{EBP} \alpha)$ and upregulation of PPAR $\gamma$. PPAR $\gamma$ is a primary regulator of fatty acid storage and glucose metabolism, and the genes activated by PPAR $\gamma$ are linked to stimulation of lipid uptake by adipocytes and adipogenesis ${ }^{(130)}$. C/EBP $\alpha$ promotes adipogenesis by inducing the expression of PPAR $\gamma^{(131)}$. The nuclear VDR appears to play an essential role in adipogenesis via $\mathrm{C} / \mathrm{EBP} \alpha$ and PPAR $\gamma$ (for example, in the absence of $1,25(\mathrm{OH})_{2} \mathrm{D}$, 'knock-down' of the VDR using siRNA delays the formation of adipocytes ${ }^{(132)}$ ).

It is worth mentioning that 'pharmacological' concentrations of $1,25(\mathrm{OH})_{2} \mathrm{D}(10-100 \mathrm{nmol} / \mathrm{l})$ are used in in vitro studies. Under normal physiological conditions, the serum circulating concentration of $1,25(\mathrm{OH})_{2} \mathrm{D}$ is tightly regulated at the level of $100-125 \mathrm{pmol} / 1$, and normal levels of $1,25(\mathrm{OH})_{2} \mathrm{D}$ in blood can be maintained within a wide range of $25(\mathrm{OH}) \mathrm{D}$ concentrations $(10-250 \mathrm{nmol} /$ $1)^{(21)}$. On the other hand, concentrations of $1,25(\mathrm{OH})_{2} \mathrm{D}$ in different tissues can approach a nanomolar range due to in situ biosynthesis of the hormone ${ }^{(21,74)}$. Therefore, it is difficult to make a direct comparison of in vitro studies using $1,25(\mathrm{OH})_{2} \mathrm{D}$ and clinical studies using either supplementation with vitamin D or measuring the circulating concentration of $25(\mathrm{OH}) \mathrm{D}$.

\section{Calcium and lipid metabolism}

$\mathrm{Ca}^{2+}$ may play a role in the regulation of lipid metabolism and TAG storage. The hypothesis advocated by Zemel \& Sun ${ }^{(133)}$ suggests that depressed levels of $1,25(\mathrm{OH})_{2} \mathrm{D}$ (due to a high dietary Ca intake) cause a decrease in intracellular $\mathrm{Ca}^{2+}$ concentration, and, thus, stimulate lipolysis, and inhibit fatty acid synthase and de novo lipogenesis. However, a basal, steady-state intracellular $\mathrm{Ca}^{2+}$ concentration is maintained by mechanisms (pumps and buffers) independent of $\mathrm{Ca}$ intake, and a decrease in circulating $1,25(\mathrm{OH})_{2} \mathrm{D}$ will not directly affect basal intracellular $\mathrm{Ca}^{2+}$ concentration. Interestingly, Sampath et al. ${ }^{(134)}$ administered $1500 \mathrm{mg}$ supplemental Ca per d for 3 months to overweight or obese subjects and measured the rates of lipolysis in adipose tissue, whole-body lipid oxidation and circulating concentrations of several hormones. They failed to demonstrate the effect of $\mathrm{Ca}$ supplementation on the rate of lipid oxidation or lipolysis. This was confirmed in the study by Bortolotti et al. ${ }^{(135)}$, where subjects receiving $800 \mathrm{mg}$ dairy $\mathrm{Ca}$ per $\mathrm{d}$ for 5 weeks demonstrated no effects of $\mathrm{Ca}$ supplementation on markers of lipid metabolism. 


\section{Vitamin D and mitochondrial uncoupling proteins}

An increase in the expression of mitochondrial uncoupling proteins (UCP) promotes a shift toward thermogenesis and away from ATP synthesis. As ATP production diminishes, the dynamics of the catabolic breakdown and biosynthesis of stored nutrients shifts toward catabolism in an effort to replenish the ATP stores ${ }^{(136)}$. Theoretically, therefore, a higher expression of UCP could be beneficial for bodyfat loss. The study conducted by Sun \& $\mathrm{Zemel}^{(137)}$ found that treatment of human adipocytes with $1,25(\mathrm{OH})_{2} \mathrm{D}_{3}$ inhibits UCP-2 mRNA and the protein level via a mechanism linked to the nuclear VDR. The potential role of UCP was also demonstrated in the normocalcemic, VDR knockout mouse ${ }^{(17)}$. The lean phenotype of VDR knockout mice was characterised by a reduced serum leptin concentration, a compensatory increase of food intake and was associated with elevated levels of UCP-1 in adipose tissue. These studies show that $1,25(\mathrm{OH})_{2} \mathrm{D}_{3}$ may suppress UCP expression in adipocytes. However, such an effect would not necessarily contribute to fat accumulation in normal adipose tissue because ATP synthesis by mitochondria is tightly regulated, and physiological thermogenesis occurs mainly in brown adipose tissue.

\section{Conclusion}

The reviewed observational studies indicate that higher $\mathrm{Ca}$ intake and increased vitamin D status are inversely associated with body weight and fat in humans. However, intervention studies examining the effect of dietary $\mathrm{Ca}$ and vitamin D status on body-fat mass and body weight are inconclusive. Emerging data provide a mechanistic framework for evaluating the role of $\mathrm{Ca}$ and vitamin $\mathrm{D}$ in adiposity and energy balance. These mechanisms include the modulation of faecal fat excretion, adipocyte apoptosis, adipogenesis and lipid metabolism, and mitochondrial UCP (see Fig. 1). Although precise molecular pathways linking vitamin D, Ca and energy balance are not identified, the evidence discussed in the present review reinforces the importance of unravelling these mechanisms to better understand the role of vitamin $\mathrm{D}$ and $\mathrm{Ca}$ in the prevention of obesity and overweight. Conflicting results on the role of $\mathrm{Ca}$ and vitamin $\mathrm{D}$ in adipose tissue suggest that multiple factors such as Ca intake, vitamin D status, and the interactions of $\mathrm{Ca}$-vitamin $\mathrm{D}$ cellular signalling pathways may act synergistically or antagonistically to regulate energy balance and body-fat gain. Clearly, investigations on the role of $\mathrm{Ca}$ and vitamin $\mathrm{D}$ and obesity are urgently needed.

\section{Acknowledgements}

The studies by I. N. S. reviewed in this article were supported by the United States Department of Agriculture (no. SD00294-H, SD00H167-061HG and 2009-3520005008). Q. S. and I. N. S. contributed equally in the writing and revising of the manuscript. The authors declare no competing interests.

\section{References}

1. Giskes K, van Lenthe F, Avendano-Pabon M, et al. (2011) A systematic review of environmental factors and obesogenic dietary intakes among adults: are we getting closer to understanding obesogenic environments? Obes Rev 12, e95-e106.

2. World Health Organization (2009) Obesity and overweight. http://www.who.int/mediacentre/factsheets/fs311/en/ index.html

3. Ogden CL, Yanovski SZ, Carroll MD, et al. (2007) The epidemiology of obesity. Gastroenterology 132, 2087-2102.

4. Maury E \& Brichard SM (2010) Adipokine dysregulation, adipose tissue inflammation and metabolic syndrome. $\mathrm{Mol}$ Cell Endocrinol 314, 1-16.

5. Solomon CG \& Manson JE (1997) Obesity and mortality: a review of the epidemiologic data. Am J Clin Nutr 66, 1044S-1050S.

6. Hedley AA, Ogden CL, Johnson CL, et al. (2004) Prevalence of overweight and obesity among US children, adolescents, and adults, 1999-2002. JAMA 291, 2847-2850.

7. United States Department of Agriculture (2010) Lossadjusted food availability. http://www.ers.usda.gov/Data/ FoodConsumption/FoodGuideIndex.htm\#calories

8. Maes HH, Neale MC \& Eaves LJ (1997) Genetic and environmental factors in relative body weight and human adiposity. Behav Genet 27, 325-351.

9. Lane MD \& Tang QQ (2005) From multipotent stem cell to adipocyte. Birth Defects Res A Clin Mol Teratol 73, 476-477.

10. Clement K, Vaisse C, Lahlou N, et al. (1998) A mutation in the human leptin receptor gene causes obesity and pituitary dysfunction. Nature 392, 398-401.

11. Gesta S, Tseng YH \& Kahn CR (2007) Developmental origin of fat: tracking obesity to its source. Cell 131, 242-256.

12. Abate N \& Garg A (1995) Heterogeneity in adipose tissue metabolism: causes, implications and management of regional adiposity. Prog Lipid Res 34, 53-70.

13. Porter SA, Massaro JM, Hoffmann U, et al. (2009) Abdominal subcutaneous adipose tissue: a protective fat depot? Diabetes Care 32, 1068-1075.

14. Yusuf S, Hawken S, Ounpuu S, et al. (2004) Effect of potentially modifiable risk factors associated with myocardial infarction in 52 countries (the INTERHEART study): case-control study. Lancet 364, 937-952.

15. Haugen F \& Drevon CA (2007) The interplay between nutrients and the adipose tissue. Proc Nutr Soc 66, $171-182$

16. Ashton KG (2002) Patterns of within-species body size variation of birds: strong evidence for Bergmann's rule. Global Ecol and Biogeogr 11, 505-523.

17. Narvaez CJ, Matthews D, Broun E, et al. (2009) Lean phenotype and resistance to diet-induced obesity in vitamin D receptor knockout mice correlates with induction of uncoupling protein-1 in white adipose tissue. Endocrinology 150, 651-661.

18. Guerre-Millo M (2002) Adipose tissue hormones. J Endocrinol Invest 25, 855-861.

19. Fliers E \& Boelen A (2010) Type 2 deiodinase and brown fat: the heat is on - or off. Endocrinology 151, 4087-4089.

20. Carafoli E, Santella L, Branca D, et al. (2001) Generation, control, and processing of cellular calcium signals. Crit Rev Biochem Mol Biol 36, 107-260. 
21. Sergeev IN, Rhoten WB \& Spirichev VB (1998) Vitamin D and intracellular calcium. Subcell Biochem 30, 271-297.

22. Sergeev IN (2005) Calcium signaling in cancer and vitamin D. J Steroid Biochem Mol Biol 97, 145-151.

23. Sergeev IN (2009) 1,25-Dihydroxyvitamin $\mathrm{D}_{3}$ induces $\mathrm{Ca}^{2+}$ mediated apoptosis in adipocytes via activation of calpain and caspase-12. Biochem Biophys Res Commun 384, $18-21$.

24. Sergeev IN \& Norman AW (2000) 1,25-Dihydroxyvitamin $\mathrm{D}_{3}$ and calcium signaling. In Vitamin D Endocrine System: Structural, Biological, Genetic and Clinical Aspects, pp. 715-718 [AW Norman, R Bouillon and M Thomasset, editors]. Riverside: University of California.

25. Sergeev IN \& Rhoten WB (1995) 1,25-Dihydroxyvitamin $\mathrm{D}_{3}$ evokes oscillations of intracellular calcium in a pancreatic $\beta$-cell line. Endocrinology 136, 2852-2861.

26. Institute of Medicine (2011) Dietary Reference Intakes for Calcium and Vitamin D. Washington, DC: The National Academies Press.

27. United States Department of Agriculture (2010) Report of the Dietary Guidelines Advisory Committee on the Dietary Guidelines for Americans, 2010. Washington, DC: USDA.

28. Scientific Panel on Dietetic Products, Nutrition and Allergies (2006) Tolerable Upper Intake Levels for Vitamins and Minerals. Scientific Committee on Food. Parma: European Food Safety Authority.

29. Heaney RP (2006) Calcium intake and disease prevention. Arq Bras Endocrinol Metabol 50, 685-693.

30. Wright JD, Wang CY, Kennedy-Stephenson J, et al. (2003) Dietary intake of ten key nutrients for public health, United States: 1999-2000. Adv Data 334, 1-4.

31. National Institutes of Health (1994) Optimal calcium intake. http://consensus.nih.gov/1994/ 1994OptimalCalcium097html.htm

32. Pilvi TK, Harala S, Korpela R, et al. (2009) Effects of highcalcium diets with different whey proteins on weight loss and weight regain in high-fat-fed $\mathrm{C} 57 \mathrm{BL} / 6 \mathrm{~J}$ mice. $\mathrm{Br} \mathrm{J}$ Nutr 102, 337-341.

33. Eller LK \& Reimer RA (2010) A high calcium, skim milk powder diet results in a lower fat mass in male, energy-restricted, obese rats more than a low calcium, casein, or soy protein diet. J Nutr 140, 1234-1241.

34. Parra P, Bruni G, Palou A, et al. (2008) Dietary calcium attenuation of body fat gain during high-fat feeding in mice. J Nutr Biochem 19, 109-117.

35. de Wit NJ, Bosch-Vermeulen H, Oosterink E, et al. (2011) Supplementary dietary calcium stimulates faecal fat and bile acid excretion, but does not protect against obesity and insulin resistance in C57BL/6J mice. Br J Nutr 105, $1005-1011$.

36. Leite LH \& Sampaio AB (2010) Dietary calcium, dairy food intake and metabolic abnormalities in HIV-infected individuals. J Hum Nutr Diet 23, 535-543.

37. Dicker D, Belnic Y, Goldsmith R, et al. (2008) Relationship between dietary calcium intake, body mass index, and waist circumference in MABAT - the Israeli National Health and Nutrition Study. Isr Med Assoc J 10, 512-515.

38. dos Santos LC, de Padua Cintra I, Fisberg M, et al. (2008) Calcium intake and its relationship with adiposity and insulin resistance in post-pubertal adolescents. J Hum Nutr Diet 21, 109-116.

39. Palacios C, Benedetti P \& Fonseca S (2007) Impact of calcium intake on body mass index in Venezuelan adolescents. P R Health Sci J 26, 199-204.

40. Gonzalez AJ, White E, Kristal A, et al. (2006) Calcium intake and 10-year weight change in middle-aged adults. $\mathrm{J} \mathrm{Am}$ Diet Assoc 106, 1066-1073.
41. Tidwell DK \& Valliant MW (2011) Higher amounts of body fat are associated with inadequate intakes of calcium and vitamin D in African American women. Nutr Res 31, 527-536.

42. Goldberg TB, da Silva CC, Peres LN, et al. (2009) Calcium intake and its relationship with risk of overweight and obesity in adolescents. Arch Latinoam Nutr 59, 14-21.

43. Torres MR, da Silva Ferreira T, Carvalho DC, et al. (2010) Dietary calcium intake and its relationship with adiposity and metabolic profile in hypertensive patients. Nutrition 6, 666-671.

44. Wagner G, Kindrick S, Hertzler S, et al. (2007) Effects of various forms of calcium on body weight and bone turnover markers in women participating in a weight loss program. J Am Coll Nutr 26, 456-461.

45. Faghih S, Abadi AR, Hedayati M, et al. (2011) Comparison of the effects of cows' milk, fortified soy milk, and calcium supplement on weight and fat loss in premenopausal overweight and obese women. Nutr Metab Cardiovasc Dis 21, 499-503.

46. Teegarden D, White KM, Lyle RM, et al. (2008) Calcium and dairy product modulation of lipid utilization and energy expenditure. Obesity (Silver Spring) 16, 1566-1572.

47. Riedt CS, Schlussel Y, von Thun N, et al. (2007) Premenopausal overweight women do not lose bone during moderate weight loss with adequate or higher calcium intake. $\mathrm{Am}$ J Clin Nutr 85, 972-980.

48. Thomas DT, Wideman L \& Lovelady CA (2010) Effects of calcium and resistance exercise on body composition in overweight premenopausal women. J Am Coll Nutr 29, 604-611.

49. Yanovski JA, Parikh SJ, Yanoff LB, et al. (2009) Effects of calcium supplementation on body weight and adiposity in overweight and obese adults: a randomized trial. Ann Intern Med 150, 821-829.

50. Chailurkit LO, Saetung S, Thakkinstian A, et al. (2010) Discrepant influence of vitamin D status on parathyroid hormone and bone mass after two years of calcium supplementation. Clin Endocrinol (Oxf) 73, 167-172.

51. Trowman R, Dumville JC, Hahn S, et al. (2006) A systematic review of the effects of calcium supplementation on body weight. Br J Nutr 95, 1033-1038.

52. Torres MR, Francischetti EA, Genelhu V, et al. (2010) Effect of a high-calcium energy-reduced diet on abdominal obesity and cardiometabolic risk factors in obese Brazilian subjects. Int J Clin Pract 64, 1076-1083.

53. Norman AW (1979) Vitamin D: The Calcium Homeostatic Steroid Hormone. New York: Academic Press.

54. Spirichev VB \& Sergeev IN (1988) Vitamin D: experimental research and its practical application. World Rev Nutr Diet 56, 173-216.

55. Sergeev IN, Rhoten WB \& Norman AW (1997) 1,25-Dihydroxyvitamin $\mathrm{D}_{3}$, intracellular $\mathrm{Ca}^{2+}$ and apoptosis in breast cancer cells. In Vitamin D: Chemistry, Biology and Clinical Applications of the Steroid Hormone, pp. 473-474 [AW Norman, R Bouillon and M Thomasset, editors]. Riverside: University of California.

56. Sergeev IN \& Rhoten WB (1998) Regulation of intracellular calcium in human breast cancer cells. Endocrine 9, 321-327.

57. Norman AW, Nemere I, Zhou LX, et al. (1992) $1,25(\mathrm{OH})_{2^{-}}$ vitamin $\mathrm{D}_{3}$, a steroid hormone that produces biologic effects via both genomic and nongenomic pathways. J Steroid Biochem Mol Biol 41, 231-240.

58. Sergeev IN (2009) Novel mediators of vitamin D signaling in cancer and obesity. Immunol Endocr Metab Agents Med Chem 9, 153-158.

59. Nemere I, Garbi N, Hammerling GJ, et al. (2010) Intestinal cell calcium uptake and the targeted knockout of the $1,25 \mathrm{D}_{3}$-MARRS (membrane-associated, rapid response 
steroid-binding) receptor/PDIA3/Erp57. J Biol Chem 285, 31859-31866.

60. Nemere I \& Hintze K (2008) Novel hormone "receptors". J Cell Biochem 103, 401-407.

61. Sergeev IN \& Spirichev VB (1989) Are the receptors of 1,25-dihydroxyvitamin $\mathrm{D}_{3}$ vitamin $\mathrm{K}$ dependent? Biochemistry (Mosc) 54, 1325-1330.

62. Norman AW, Sergeev IN, Bishop JE, et al. (1993) Selective biological response by target organs (intestine, kidney, and bone) to 1,25-dihydroxyvitamin $\mathrm{D}_{3}$ and two analogues. Cancer Res 53, 3935-3942.

63. Farach-Carson MC, Sergeev IN \& Norman AW (1991) Nongenomic actions of 1,25-dihydroxyvitamin $\mathrm{D}_{3}$ in rat osteosarcoma cells: structure-function studies using ligand analogs. Endocrinology 129, 1876-1884.

64. Norman AW \& Silva FR (2001) Structure function studies: identification of vitamin $\mathrm{D}$ analogs for the ligand-binding domains of important proteins in the vitamin D-endocrine system. Rev Endocr Metab Disord 2, 229-238.

65. Sergeev IN (2004) Calcium as a mediator of 1,25-dihydroxyvitamin $\mathrm{D}_{3}$-induced apoptosis. J Steroid Biochem Mol Biol 89-90, 419-425.

66. Sergeev IN \& Rhoten WB (1998) Intracellular calcium, the vitamin $\mathrm{D}$ hormone and apoptosis in breast cancer cells. Mol Biol Cell 9, 251a.

67. Sergeev IN, Rhoten WB \& Carney MD (1996) Calbindins decreased after space flight. Endocrine 5, 335-340.

68. Sergeev IN \& Rhoten WB (1995) Video imaging of calcium and $\mathrm{pH}$ in breast-cancer cells. Mol Biol Cell 6, 2039.

69. Rhoten WB \& Sergeev IN (1994) Calbindin- $D_{28 \mathrm{k}}$ appears to buffer intracellular $\mathrm{Ca}^{2+}$ in butyrate-treated rat insulinoma cells. Endocrine 2, 989-995.

70. Sergeev IN \& Spirichev VB (1988) The role of vitamin K in the interaction of 1,25-dihydroxyvitamin $\mathrm{D}_{3}$ receptors with DNA (article in Russian). Biull Eksp Biol Med 106, 695-698.

71. Sergeev IN \& Norman AW (1992) Vitamin-K-dependent $\gamma$-carboxylation of the 1,25-dihydroxyvitamin- $\mathrm{D}_{3}$ receptor. Biochem Biophys Res Commun 189, 1543-1547.

72. Holick MF (1997) Photobiology of vitamin D. In Vitamin D, pp. 33-39 [D Feldman, FH Glorieux and JW Pike, editors]. San Diego: Academic Press.

73. Verreault R, Semba RD, Volpato S, et al. (2002) Low serum vitamin $\mathrm{D}$ does not predict new disability or loss of muscle strength in older women. J Am Geriatr Soc 50, 912-917.

74. Norman AW \& Bouillon R (2010) Vitamin D nutritional policy needs a vision for the future. Exp Biol Med 235, $1034-1045$.

75. Foss YJ (2009) Vitamin D deficiency is the cause of common obesity. Med Hypotheses 72, 314-321.

76. Rosenstreich SJ, Rich C \& Volwiler W (1971) Deposition in and release of vitamin $D_{3}$ from body fat: evidence for a storage site in the rat. J Clin Invest 50, 679-687.

77. Zemel MB, Shi H, Greer B, et al. (2000) Regulation of adiposity by dietary calcium. FASEB J 14, 1132-1138.

78. Aasheim ET, Hofso D, Hjelmesaeth J, et al. (2008) Vitamin status in morbidly obese patients: a cross-sectional study. Am J Clin Nutr 87, 362-369.

79. Alemzadeh R, Kichler J, Babar G, et al. (2008) Hypovitaminosis $\mathrm{D}$ in obese children and adolescents: relationship with adiposity, insulin sensitivity, ethnicity, and season. Metabolism 57, 183-191.

80. Ardawi MS, Qari MH, Rouzi AA, et al. (2011) Vitamin D status in relation to obesity, bone mineral density, bone turnover markers and vitamin D receptor genotypes in healthy Saudi pre- and postmenopausal women. Osteoporos Int 22, 463-475.
81. Beydoun MA, Boueiz A, Shroff MR, et al. (2010) Associations among 25 -hydroxyvitamin $\mathrm{D}$, diet quality, and metabolic disturbance differ by adiposity in adults in the United States. J Clin Endocrinol Metab 95, 3814-3827.

82. Brock K, Huang WY, Fraser DR, et al. (2010) Low vitamin D status is associated with physical inactivity, obesity and low vitamin D intake in a large US sample of healthy middleaged men and women. J Steroid Biochem Mol Biol 121, 462-466.

83. Elizondo-Montemayor L, Ugalde-Casas PA, Serrano-Gonzalez M, et al. (2010) Serum 25-hydroxyvitamin D concentration, life factors and obesity in Mexican children. Obesity (Silver Spring) 18, 1805-1811.

84. Herranz Antolin S, Garcia Martinez Mdel C \& Alvarez De Frutos V (2010) Vitamin D deficiency in morbidly obese patients. A case-control study. Endocrinol Nutr 57, 256-261.

85. Hypponen E \& Power C (2006) Vitamin D status and glucose homeostasis in the 1958 British birth cohort: the role of obesity. Diabetes Care 29, 2244-2246.

86. Konradsen S, Ag H, Lindberg F, et al. (2008) Serum 1,25dihydroxyvitamin $\mathrm{D}$ is inversely associated with body mass index. Eur J Nutr 47, 87-91.

87. Kremer R, Campbell PP, Reinhardt T, et al. (2009) Vitamin D status and its relationship to body fat, final height, and peak bone mass in young women. J Clin Endocrinol Metab 94, $67-73$.

88. Lagunova Z, Porojnicu AC, Lindberg F, et al. (2009) The dependency of vitamin D status on body mass index, gender, age and season. Anticancer Res 29, 3713-3720.

89. Reinehr T, de Sousa G, Alexy U, et al. (2007) Vitamin D status and parathyroid hormone in obese children before and after weight loss. Eur J Endocrinol 157, 225-232.

90. Smotkin-Tangorra M, Purushothaman R, Gupta A, et al. (2007) Prevalence of vitamin D insufficiency in obese children and adolescents. J Pediatr Endocrinol Metab 20, $817-823$.

91. Valina-Toth AL, Lai Z, Yoo W, et al. (2010) Relationship of vitamin $\mathrm{D}$ and parathyroid hormone with obesity and body composition in African Americans. Clin Endocrinol (Oxf) 72, 595-603.

92. Vilarrasa N, Maravall J, Estepa A, et al. (2007) Low 25hydroxyvitamin $\mathrm{D}$ concentrations in obese women: their clinical significance and relationship with anthropometric and body composition variables. J Endocrinol Invest 30, 653-658.

93. Yanoff LB, Parikh SJ, Spitalnik A, et al. (2006) The prevalence of hypovitaminosis D and secondary hyperparathyroidism in obese black Americans. Clin Endocrinol (Oxf) 64, 523-529.

94. Adam MA, Untch BR, Danko ME, et al. (2010) Severe obesity is associated with symptomatic presentation, higher parathyroid hormone levels, and increased gland weight in primary hyperparathyroidism. J Clin Endocrinol Metab 95, 4917-4924.

95. Johnson LK, Hofs $\varnothing$ D, Aasheim ET, et al. (2012) Impact of gender on vitamin D deficiency in morbidly obese patients: a cross-sectional study. Eur J Clin Nutr 66, 83-90.

96. Pacifico L, Anania C, Osborn JF, et al. (2011) Low $25(\mathrm{OH}) \mathrm{D}_{3}$ levels are associated with total adiposity, metabolic syndrome, and hypertension in Caucasian children and adolescents. Eur J Endocrinol 165, 603-611.

97. Renzaho AM, Halliday JA \& Nowson C (2011) Vitamin D, obesity, and obesity-related chronic disease among ethnic minorities: a systematic review. Nutrition 27, 868-879.

98. Vashi PG, Lammersfeld CA, Braun DP, et al. (2011) Serum 25-hydroxyvitamin $\mathrm{D}$ is inversely associated with body mass index in cancer. Nutr J 10, 51 . 
99. Rajakumar K, de las Heras J, Chen TC, et al. (2011) Vitamin D status, adiposity, and lipids in black American and Caucasian children. J Clin Endocrinol Metab 96, 1560-1567.

100. Lagunova Z, Porojnicu AC, Lindberg FA, et al. (2011) Vitamin D status in Norwegian children and adolescents with excess body weight. Pediatr Diabetes 12, 120-126.

101. World Health Organization (2000) Obesity: Preventing and Managing the Global Epidemic. Report of a WHO Consultation, WHO Technical Report Series no. 894. Geneva: WHO.

102. Sharma S, Barr AB, Macdonald HM, et al. (2011) Vitamin D deficiency and disease risk among aboriginal Arctic populations. Nutr Rev 69, 468-478.

103. Mawer EB, Backhouse J, Holman CA, et al. (1972) The distribution and storage of vitamin D and its metabolites in human tissues. Clin Sci 43, 413-431.

104. Zittermann A, Frisch S, Berthold HK, et al. (2009) Vitamin D supplementation enhances the beneficial effects of weight loss on cardiovascular disease risk markers. Am J Clin Nutr 89, 1321-1327.

105. Sneve M, Figenschau Y \& Jorde R (2008) Supplementation with cholecalciferol does not result in weight reduction in overweight and obese subjects. Eur $J$ Endocrinol 159, 675-684.

106. Major GC, Alarie F, Dore J, et al. (2007) Supplementation with calcium + vitamin D enhances the beneficial effect of weight loss on plasma lipid and lipoprotein concentrations. Am J Clin Nutr 85, 54-59.

107. Holecki M, Zahorska-Markiewicz B, Wiecek A, et al. (2008) Influence of calcium and vitamin D supplementation on weight and fat loss in obese women. Obes Facts 1, 274-279.

108. Zhou J, Zhao LJ, Watson P, et al. (2010) The effect of calcium and vitamin D supplementation on obesity in postmenopausal women: secondary analysis for a large-scale, placebo controlled, double-blind, 4-year longitudinal clinical trial. Nutr Metab (Lond) 7, 62 .

109. Caan B, Neuhouser M, Aragaki A, et al. (2007) Calcium plus vitamin D supplementation and the risk of postmenopausal weight gain. Arch Intern Med 167, 893-902.

110. Buchowski MS, Aslam M, Dossett C, et al. (2010) Effect of dairy and non-dairy calcium on fecal fat excretion in lactose digester and maldigester obese adults. Int J Obes (Lond) 34, 127-135.

111. Christensen R, Lorenzen JK, Svith CR, et al. (2009) Effect of calcium from dairy and dietary supplements on faecal fat excretion: a meta-analysis of randomized controlled trials. Obes Rev 10, 475-486.

112. Reed JC (2002) Apoptosis-based therapies. Nat Rev Drug Discov 1, 111-121.

113. Prins JB \& O'Rahilly S (1997) Regulation of adipose cell number in man. Clin Sci (Lond) 92, 3-11.

114. Berridge MJ, Bootman MD \& Lipp P (1998) Calcium - a life and death signal. Nature 395, 645-648.

115. Orrenius S, Zhivotovsky B \& Nicotera P (2003) Regulation of cell death: the calcium-apoptosis link. Nat Rev Mol Cell Biol 4, 552-565.

116. Sergeev IN, Colby J \& Norman AW (2000) 1,25-Dihydroxyvitamin $\mathrm{D}_{3}$ triggers calcium-mediated apoptosis in breast cancer cells. In Vitamin D Endocrine System: Structural, Biological, Genetic and Clinical Aspects, pp. 399-402 [AW Norman, R Bouillon and M Thomasset, editors]. Riverside: University of California.

117. Mathiasen IS, Sergeev IN, Bastholm L, et al. (2002) Calcium and calpain as key mediators of apoptosis-like death induced by vitamin D compounds in breast cancer cells. J Biol Chem 277, 30738-30745.
118. Sergeev IN \& Norman AW (2003) Calcium as a mediator of apoptosis in bovine oocytes and preimplantation embryos. Endocrine 22, 169-176.

119. McConkey DJ \& Orrenius S (1997) The role of calcium in the regulation of apoptosis. Biochem Biophys Res Commun 239, 357-366.

120. Welsh J, VanWeelden K, Flanagan L, et al. (1998) The role of vitamin $\mathrm{D}_{3}$ and antiestrogens in modulating apoptosis of breast cancer cells and tumors. Subcell Biochem 30, 245-270.

121. Carafoli E \& Molinari M (1998) Calpain: a protease in search of a function? Biochem Biophys Res Commun 247, $193-203$.

122. Ho PK \& Hawkins CJ (2005) Mammalian initiator apoptotic caspases. FEBS J 272, 5436-5453.

123. Oubrahim H, Chock PB \& Stadtman ER (2002) Manganese(II) induces apoptotic cell death in NIH3T3 cells via a caspase-12-dependent pathway. $J$ Biol Chem 277, 20135-20138.

124. Nakagawa T, Zhu H, Morishima N, et al. (2000) Caspase-12 mediates endoplasmic-reticulum-specific apoptosis and cytotoxicity by amyloid- $\beta$. Nature $\mathbf{4 0 3}, 98-103$.

125. Welsh J \& Byrne B (2007) Identification of novel mediators of vitamin $\mathrm{D}$ signaling and $1,25(\mathrm{OH})_{2} \mathrm{D}_{3}$ resistance in mammary cells. J Steroid Biochem Mol Biol 103, 703-707.

126. Sergeev IN, Li S, Ho CT, et al. (2009) Polymethoxyflavones activate $\mathrm{Ca}^{2+}$-dependent apoptotic targets in adipocytes. J Agric Food Chem 57, 5771-5776.

127. Sergeev IN, Ho CT, Li S, et al. (2007) Apoptosis-inducing activity of hydroxylated polymethoxyflavones and polymethoxyflavones from orange peel in human breast cancer cells. Mol Nutr Food Res 51, 1478-1484.

128. Sergeev IN, Li S, Colby J, et al. (2006) Polymethoxylated flavones induce $\mathrm{Ca}^{2+}$-mediated apoptosis in breast cancer cells. Life Sci 80, 245-253.

129. Kong J \& Li YC (2006) Molecular mechanism of 1,25-dihydroxyvitamin $\mathrm{D}_{3}$ inhibition of adipogenesis in 3T3-L1 cells. Am J Physiol Endocrinol Metab 290, E916-E924.

130. Jones JR, Barrick C, Kim KA, et al. (2005) Deletion of PPAR $\gamma$ in adipose tissues of mice protects against high fat dietinduced obesity and insulin resistance. Proc Natl Acad Sci U S A 102, 6207-6212.

131. Clarke SL, Robinson CE \& Gimble JM (1997) CAAT/enhancer binding proteins directly modulate transcription from the peroxisome proliferator-activated receptor $\gamma 2$ promoter. Biochem Biophys Res Commun 240, 99-103.

132. Blumberg JM, Tzameli I, Astapova I, et al. (2006) Complex role of the vitamin $\mathrm{D}$ receptor and its ligand in adipogenesis in 3T3-L1 cells. $J$ Biol Chem 281, 11205-11213.

133. Zemel MB \& Sun X (2008) Calcitriol and energy metabolism. Nutr Rev 66, S139-S146.

134. Sampath V, Havel PJ \& King JC (2008) Calcium supplementation does not alter lipid oxidation or lipolysis in overweight/obese women. Obesity (Silver Spring) 16, $2400-2404$

135. Bortolotti M, Rudelle S, Schneiter P, et al. (2008) Dairy calcium supplementation in overweight or obese persons its effect on markers of fat metabolism. Am J Clin Nutr $\mathbf{8 8}$, $877-885$.

136. Nedergaard J, Ricquier D \& Kozak LP (2005) Uncoupling proteins: current status and therapeutic prospects. EMBO Rep 6, 917-921.

137. Sun X \& Zemel MB (2004) Role of uncoupling protein 2 (UCP2) expression and $1 \alpha, 25$-dihydroxyvitamin $\mathrm{D}_{3}$ in modulating adipocyte apoptosis. FASEB J 18, 1430-1432. 